Article

\title{
Interest Groups in Multi-Level Contexts: European Integration as Cross-Cutting Issue in Party-Interest Group Contacts
}

\author{
Joost Berkhout, Marcel Hanegraaff * and Patrick Statsch \\ Department of Political Science, University of Amsterdam, 1001 NB Amsterdam, The Netherlands; \\ E-Mails: d.j.berkhout@uva.nl (J.B.),m.c.hanegraaff@uva.nl (M.H.), p.d.statsch@uva.nl (P.S.) \\ * Corresponding author
}

Submitted: 30 September 2019 | Accepted: 27 November 2019 | Published: 13 February 2020

\begin{abstract}
Policy-specific actor-constellations consisting of party- and group-representatives commonly drive the effective establishment of new policy programmes or changes in existing policies. In the EU multi-level system, the creation of such constellations is complicated because it practically requires consensus on two dimensions: the European public policy at stake and the issue of European integration. This means that, for interest groups with interests in particular policy domains, and with limited interest in the actual issue of European integration, non-Eurosceptic parties must be their main ally in their policy battles. We hypothesise that interest groups with relevant European domain-specific interests will ally with nonEurosceptic parties, whereas interest groups whose interests are hardly affected by the European policy process will have party-political allies across the full range of positions on European integration. We assess this argument on the basis of an elite-survey of interest group leaders and study group-party dyads in several European countries (i.e., Belgium, Lithuania, Italy, Netherlands, Poland, and Slovenia) in a large number of policy domains. Our dependent variable is the group-party dyad and the main independent variables are the European policy interests of the group and the level of Euroscepticism of the party. We broadly find support for our hypotheses. The findings of our study speak to the debate concerning the implications of the politicisation of European integration and, more specifically, the way in which party-political polarisation of Europe may divide domestic interest group systems and potentially drive group and party systems apart.
\end{abstract}

\section{Keywords}

European integration; Euroscepticism; interest groups; political parties

\section{Issue}

This article is part of the issue "Political Behavior in the EU Multi-Level System" edited by Daniela Braun (LMU Munich, Germany), Martin Gross (LMU Munich, Germany) and Berthold Rittberger (LMU Munich, Germany).

(C) 2020 by the authors; licensee Cogitatio (Lisbon, Portugal). This article is licensed under a Creative Commons Attribution 4.0 International License (CC BY).

\section{Introduction}

There was a time in which EU decisions could be safely explained on the basis of intra-institutional bargaining between ministries and among the EU institutions. Multi-layered institutional complexity isolated the politics among these actors in such a way that they 'seem to deal first of all with each other and not with the demand side of politics, be that the interest groups or the European electorate' (Pappi \& Henning, 1999, p. 279). Contemporary scholarship, however, does not assume or observe the full insulation of bureaucratic, narrowly scoped policymaking networks. It is far more sensitive to the circumstances that lead policymakers to be 'responsive' to political pressures in terms of public opinion, party politics, or interest groups (e.g., de Bruycker, 2017, 2019; Judge \& Thomson, 2019; Rasmussen, Carroll, \& Lowery, 2014; Rauh, 2019; Schneider, 2018). In addition, research interests not only relate to the potential implications of the broader saliency of policy issues on the EU agenda (e.g., Beyers, Dür, \& Wonka, 2018; Hanegraaff \& Berkhout, 2018) but also addresses the politicisation of the EU as a system or European integration as a process (e.g., de Wilde, Leupold, \& Schmidtke, 
2016; Hutter \& Kriesi, 2019), most dramatically observed in contemporary British politics (de Vries, 2018a; Hobolt, 2016). The latter studies indicate a substantial reconfiguration of several party systems in Western Europe, with anti-EU positions featuring heavily on the 'new' cleavage (e.g., Hooghe \& Marks, 2018; Marks, Hooghe, Nelson, \& Edwards, 2006) and at least some sensitivity to contextual, 'demand-side,' political factors within narrow, public policy niches (e.g., Klüver, Braun, \& Beyers, 2015). These circumstances merit a broad conception of EU multi-level politics as taking place in both domestic and European political arenas, affecting a broad range of policy topics and including various types of political actors and their relationships.

The more specific question central to this article is the extent to which opposing party-political views on European integration also affect the patterns of contacts between interest groups and legislative policymakers in domestic politics. Are EU positions a divisive (or decisive) factor in party-interest group contacts, in which interest groups avoid anti-EU parties? Or do interest groups align mostly with their closest, policy area-specific party allies regardless of their EU positions? The answer to this issue may indicate that EU-related party-political cleavages, and their broader salience in contemporary public and political debate, do not spill-over into policy-specific relationships with interest groups. Previous studies indicate that policy-specific elite actor constellations consisting of party- and group-representatives drive the effective establishment of new policy programmes or changes in existing policies (e.g., Grossmann, 2014). In the EU multi-level system, the creation of such constellations is complicated because it practically requires consensus on two dimensions: the European public policy at stake and the issue of European integration (e.g., de Vries, 2018b). In theoretical terms, this is a 'conflict of conflicts' within which actors have to decide 'which battle do we want most to win?' (Schattschneider, 1960, p. 65). We argue that interest groups will always stay close to their policy-specific interests rather than the broader issue of European integration. For interest groups with interests in particular policy domains, and with limited interest in the actual issue of European integration, this means that parties with favourable or moderate views on European integration must be their principal allies in policy battles. We hypothesise that interest groups with relevant European domain-specific interests will ally with parties that have favourable views on the European integration process, whereas interest groups whose policy interests are domestic in nature will have party-political allies across the full range of party-political positions on European integration.

Our article contributes to several debates. First, by focussing on the importance of EU positions of parties and interest groups, we start bridging the studies on (national) party system dimensionality, interest group networking, and (EU) public policy decisions. This research integration, in the longer term, potentially im- proves our understanding of the outcomes of national and EU public policy and facilitates the normative evaluation of those outcomes. Second, we theoretically further develop issue-specific explanations for party-group contacts (e.g., Berkhout, Hanegraaff, \& Statsch, 2019). We argue that party-group contact is importantly shaped by the particular constellation of actors within (multi-level) policy fields in combination with the longer term, dimensional structuration of political conflict in the party system. More specifically, we assess what happens when party-political conflict on European integration crosscuts the (potential) group-party relations in multi-level or domestic policy areas.

The article is structured as follows. We first proceed with a further specification of our hypothesis and its relation to the 'standard model' of party-group ties. We subsequently present our analysis on the basis of the Comparative Interest Group (CIG) Survey of leaders of interest groups in Belgium, the Netherlands, Italy, Slovenia, and Lithuania. We estimate logistic regression models on a large number of party-group dyads to test our hypotheses. We conclude with a discussion of our findings and provide a pathway for future research.

\section{Theory: The 'Conflict of Conflicts' and the Standard Model}

Why do interest groups and parties interact with each other? We conceive of political parties and interest groups as policy-oriented organisations; parties attempt to influence public policy by means of winning elections and interest groups do so without aspiration to hold elected office (Bawn et al., 2012; Burstein, 1998; Farrer, 2014; Fraussen \& Halpin, 2018; Jordan, Halpin, \& Maloney, 2004). These conceptions heavily emphasise the shaping of the political agenda and policy decisionmaking rather than the electoral connection of parties or the membership base of interest groups. This implies that the relationship between these actors is largely observed in the concrete political battles on issues related to the operation of government. This conceptually (though not necessarily empirically) differs somewhat from studies of the organisational ties of interest groups and political parties (e.g., Allern et al., 2019). Through these political conflicts, in other words, parties and interest groups organise issues into politics and do so in a manner that reduces or enhances the issue-specific contacts between certain types of political parties and interest groups. This leads political parties and interest groups to be organised around relatively similar conflicts, attend to similar issues and have patterns of contact that follow from their issuepriorities and positions. We find this argument in theories of political conflict (parties are stronger) and of the policy process (issues are contagious).

Theories of political conflict posit that political parties are stronger than other actors and the party system agenda dominates all others. This is so because only representatives of political parties actually govern and 
will, from that position, outperform others in 'structuring the world so you can win' (Riker, 1996, p. 9). This, as theorised by Schattschneider (1960, pp. 64-65), leads to a displacement of smaller conflicts in such a manner that 'every major conflict [among political parties] overwhelms, subordinates, and blots out a multitude of lesser ones [among other actors].' This 'contagiousness' of party-political differences on major dimensions of conflict such as European integration, must therefore affect 'small' conflict on particular policies. Political parties also 'freeze' conflict in the party system, subjecting historically established political oppositions and collaborations within and between parties to strong inertia (e.g., Mair, 1997). The ideological underpinnings of these cleavages guarantee a relatively strong organisational integration of the different agendas (Lipset \& Rokkan, 1967). Most notably, this is the case for social democratic parties and trade unions (e.g., Allern \& Bale, 2012). The nature of the party system also produces strong strategic incentives to avoid issues that may divide a government coalition or parties internally (e.g., Hobolt \& de Vries, 2015; van der Brug \& van Spanje, 2009). This, in turn, leads to a 'closed' political opportunity structure that necessitates interest groups align themselves with partypolitical friends (Beyers, de Bruycker, \& Baller, 2015; Hall \& Deardorff, 2006).

In more policy-related terms, a similarity in political focus may arise from parties and organised interests simultaneously working on the same political issues, or all being part of the same political 'bandwagon' (e.g., Baumgartner \& Leech, 2001). Relatively central political actors provide 'cues' on their issue priorities and, similar to a herd of sheep, follow each other in distinct policy battles (Halpin, 2011). This provides opportunities for movements to successfully bargain over political resources with elite allies (e.g., Burstein, Einwohner, \& Hollander, 1995; Císař \& Vráblíková, 2019), or for groups to influence the agenda of political parties (Klüver, 2018). These mechanisms facilitate the 'contagion' of one issue with others and connect smaller policy oppositions to larger dimensions of (party-political) conflicts.

These arguments lead us to expect that the oppositions among political parties are replicated on any minor policy issue that may arise in the day-to-day business of government. Any change in the dominant dimension of conflict among political parties therefore must have implications for the infinite issues that potentially appear in the narrow venues of (multi-level) policymaking. As suggested in the introduction, such a change in the dimensionality of party politics seems currently on-going: Socio-cultural issues such as immigration and European integration have partially displaced socio-economic ones such as labour market policy and financial regulation in the composition of the main dimension of conflict in contemporary European party politics (e.g., de Vries, 2018b; de Vries, Hakhverdian, \& Lancee, 2013; Hoeglinger, 2016; Hutter \& Kriesi, 2019; Marks et al., 2006; Szczerbiak \& Taggart, 2008; van Elsas \& van der Brug, 2015). Left- and right-wing Eurosceptic parties dynamically and strategically connect to the distinct core issues on the agendas of European party systems (e.g., Braun, Popa, \& Schmitt, 2019; Meijers \& Rauh, 2016). We are dealing with party-based Euroscepticism that occurs when a political party expresses the idea of contingent or qualified opposition, as well as incorporating outright and unqualified opposition to the process of European integration' (Szczerbiak \& Taggart, 2008; Taggart, 1998, p. 360). Several policy crises also seem to have produced a fertile ground for challenger parties to combine populism with anti-European integration positions, as noted by Pirro, Taggart, and van Kessel (2018, p. 388), 'the cocktail of anti-establishment populist parties with the increasing politicisation of European integration as an issue in domestic polities is an unmistakably powerful one.'

Given this change, we should observe that interest groups with long-term policy-specific priorities avoid parties voicing concerns on 'new' issues, most notably European integration, that crosscut their prime policy objectives. For instance, an environmental NGO may eschew a social democratic party which expresses an antiEU sentiment as this may hurt their policy objective in the long term even if the party does express a proenvironmental position. The same applies to business associations. If their membership profits significantly from EU trade, such associations may exclude right-wing economic parties which express strong anti-EU positions. The benefit they may gain from any economic alignment on national politics may be surpassed by the effects of the anti-EU message of the party. This tension should become particularly pronounced in policy communities active in areas with strong EU policy competence and may subsequently affect contact between interest groups and parties (e.g., Rasmussen, 2012; Wonka, 2017). In less abstract terms, interest groups for whom relevant policy issues are addressed at the EU level, or in a multi-level fashion, will not have much contact with Eurosceptic parties because it makes their multi-level policy involvement difficult.

All this leads to the following hypothesis. First, we expect that interest groups for whom policies originating from the EU are of distinct importance, tend to prioritise contact with parties with a pro-EU position compared to other parties. Second, interest groups whose policy interests are predominantly domestic in nature maintain contacts with parties regardless of their position on European integration. In sum:

H1: The more interest groups are affected by policies originating at the EU level, the more likely it is that they have contacts with political parties with relatively favourable views on European integration;

$\mathrm{H} 2$ : If interest groups are mostly affected by policies originating at the national level, views on European integration by political parties do not affect the contacts between interest groups and parties. 
We control for what we label the 'standard model' for party-group contact (e.g., Berkhout et al., 2019). This 'model' is the result of a wave of recent studies on policy-specific contacts and long-term organisational exchange-relationships between political parties and interest groups (Allern \& Bale, 2012; Allern et al., 2019; Beyers et al., 2015; Bolleyer, 2017; de Bruycker, 2016; Otjes \& Rasmussen, 2017; Rasmussen \& Lindeboom, 2013). To begin, interest groups are attracted to power and particularly aim to interact with parties or legislators that have the capabilities to influence the direction of public policy. This concerns both legislative and executive power (we expect the latter to be particularly attractive, given the relation to the bureaucracy). Furthermore, parties and groups whose political positions are close to each other are commonly found to have more frequent policy-specific contacts, as well as structural organisational relations (Allern et al., 2019). Finally, representatives of political parties are likely to appreciate interest groups capable of delivering relevant policy information across a diverse range of topics.

\section{Data and Research Design}

We use the CIG survey data (Beyers et al., 2016). In this project, national interest group populations were surveyed in Belgium, Italy, Lithuania, the Netherlands, and Slovenia. Translated versions of the same online questionnaire were used to elicit answers concerning organisational characteristics, political activities, and strategies. Our dataset contains information on 2,067 interest groups and their interactions with the most relevant national parties $(n=38)$ in 2017 and 2018 (for more information on the details of the survey see www.cigsurvey.eu). Please note that more countries are included in this project, most notably Sweden. We do not include the Swedish data because several of the questions that we rely upon in our study were not asked. The countries included span Western (the Netherlands, Belgium), Eastern (Lithuania and Slovenia), and Southern Europe (Italy), and differ substantially in their institutional histories of state-society relations and the particular development of their party and interest-group systems. More particularly, these countries differ substantially in the extent to which European integration is a salient and polarised issue in party politics (see Supplementary Material for EU positions and salience for all parties included in the analyses). This diversity creates relatively high generalisability of our findings, particularly within the European context.

We reshaped our interest group-level data into a dataset in which group-party dyads ( $n=16,514)$ form the unit of analysis (Hanegraaff \& Pritoni, 2019). This dyadic data structure matches the relational nature of our explanandum (group-party contact) and allows us to simultaneously include interest group and party explanatory factors in a single model, most notably, interest groups' interest in policies originating from the EU and parties' positions towards European integration. In this dyadic data structure, our observations are clustered by groups and parties, and we therefore estimate all our models in a multi-level way with group- and party-level random intercepts.

As for our dependent variable, the CIG survey asks interest group representatives to indicate the frequency of contact between their organisation and relevant national legislative political parties over the previous 12 months. Respondents were presented with a list of parties and could indicate the frequency of their contacts on a fivepoint scale ('never' to 'at least once a week'). We recoded this variable into a dummy variable to indicate whether a group and a party had none (0) or any (1) contact. This binary contact indicator forms the dependent variable of our analyses and we estimate logistic regression models accordingly. This question covers contact on any type of issue; it may be about particular EU-related developments but in most cases is likely to refer to domestic legislative politics. This is a valid measure because we would like to know whether party-political pro- or anti-European integration positions affect interest group-party contact, and, given conflict contagiousness, whether it is plausible to affect any contact, rather than only those pertaining to EU policies or only those between EU actors.

Overall, $62 \%$ of the interest groups in our sample indicated that they had any contact with political parties over the previous 12 months. At the group-party dyad level, contact was established in $41 \%$ of the logically possible cases. These patterns of interaction are comparable with levels of contact with the national government (contacted by $64 \%$ of the groups), but much higher than contact with European institutions (European Commission: 21\%; European Parliament: $29 \%$ ). The $38 \%$ of the respondents without any party-political contact tend to be 'latent' groups whose political interests are only sporadically triggered by particular social or political 'disturbances' (Truman, 1951) rather than a structural feature of the organisation (as is indicated by the strong correlation between party contacts and government contacts: Spearman's $\rho=.6 ; \mathrm{p}<.001)$.

Our central independent variables are group-, party-, and dyad-specific. To begin with the group level, we measured interest groups' interests in EU public policies based on the responses to the survey question: 'Policies originating from the European Union have a different level of importance for different organisations. How important are these policies for your organisation?' (Beyers et al., 2016). Respondents could answer on a 4-point scale ranging from $1=$ 'EU policies are of no importance whatsoever' to $4=$ 'EU policies are the most important focus.' We combine the 'important' and 'most important' answer categories, since only $2 \%$ of our respondents used the highest category.

We derive the position on European integration of political parties from the 2014 Chapel Hill Expert Survey (CHES; Polk et al., 2017). The variable EU position ranges from strongly opposed to European integration (1) to 
strongly in favour of European integration (7). We assess our central hypothesis on the basis of an interaction term of our measures of groups' interests in EU public policy and parties' stance on the issue of European integration.

Patterns of contact between interest groups and parties are affected by many factors other than just the configuration of groups' and parties' interests related to Europe. We therefore control for an extensive list of potentially confounding factors, labelled 'the standard model' above. Concerning the interest group side we rely on the CIG survey to measure group resources (logged number of staff) and the breadth of a group's policy engagement (number of policy fields active in). These factors increase the likelihood of contact with political parties across the board. That is, staff resources enable interest groups to contact many parties and the breadth of a group's policy engagement signifies its overall interest in public policy. Our interest group survey includes questions that tap into similar or adjacent characteristics. However, to avoid multicollinearity between our factors we do not include these in the model. There are a small number of respondents whose central cause is directly related to supporting or rejecting the process of European integration, such as the country chapters of the European Movement International. We also control for different group types (adapted from the INTERARENA coding scheme, www.interarena.dk).
Regarding the party side, we control for the salience of the topic of European integration to disentangle the effects of positions and salience, based on CHES data (Polk et al., 2017). To account for interest groups' inclination to contact powerful parties, we include, first, the legislative seat share (in percentage points) that a given party held after the most recent election before the CIG survey was set out. Second, we indicate government coalition participation during the time of the survey and, last, party institutionalisation (logged age; based on Döring \& Manow, 2018). Interest groups may prefer to interact with ideologically moderate parties in order to avoid dissensus among their (potential) members (e.g., Lowery \& Gray, 2004, pp. 10-11; Salisbury, 1969). We therefore include measures of the ideological positions of parties along the general left-right (based on Volkens et al., 2017), and green-alternative-libertarian (GAL)-traditional-authoritarian-nationalist (TAN) dimensions (Polk et al., 2017), as well as their squared transformations. We also control for populist parties, which are less likely to be contacted by interest groups (Berkhout et al., 2019). Lastly, we include country dummies (fixed effects) to account for the different baseline probabilities of contact in our five countries of observation. Table 1 provides the summary statistics of all variables used for the 16,514 dyads included in our analyses.

Table 1. Summary statistics.

\begin{tabular}{|c|c|c|c|c|}
\hline & mean & s.d. & $\min$ & $\max$ \\
\hline DV: Contact & 0.41 & & 0 & 1 \\
\hline \multicolumn{5}{|l|}{ Independent variables } \\
\hline \multicolumn{5}{|l|}{ IG interest in EU public policies: } \\
\hline no importance whatsoever & 0.18 & & 0 & 1 \\
\hline less important & .46 & & 0 & 1 \\
\hline important/most important & 0.35 & & 0 & 1 \\
\hline EU position & 5.12 & 1.68 & 1.09 & 6.82 \\
\hline \multicolumn{5}{|l|}{ Party-level controls } \\
\hline EU salience & 5.23 & 1.73 & 2.87 & 8.86 \\
\hline Left-Right position & 4.91 & 0.88 & 2.55 & 6.97 \\
\hline GAL-TAN position & 4.92 & 2.63 & 1 & 9.44 \\
\hline Seat share & 10.86 & 9.27 & 0 & 47.30 \\
\hline Government & 0.35 & & 0 & 1 \\
\hline Populist & 0.17 & & 0 & 1 \\
\hline Institutionalisation (Party age logged) & 3.25 & 0.66 & 1.39 & 4.58 \\
\hline \multicolumn{5}{|l|}{ IG-level controls } \\
\hline Breadth of policy engagement & 3.27 & 3.35 & 0 & 22 \\
\hline Resources (\#Staff logged) & 1.08 & 1.38 & 0 & 8.99 \\
\hline \multicolumn{5}{|l|}{ Group Type: } \\
\hline Business group & .44 & & 0 & 1 \\
\hline Citizen group & .31 & & 0 & 1 \\
\hline Institutional group & .06 & & 0 & 1 \\
\hline Union & .04 & & 0 & 1 \\
\hline Other & .14 & & 0 & 1 \\
\hline
\end{tabular}

Notes: $\mathrm{N}_{\text {Dyads }}: 16,514 ; \mathrm{N}_{\text {Groups }}: 2,067 ; \mathrm{N}_{\text {Parties }}: 38$. 


\section{Analysis}

Table 2 presents two logistic regression models testing our expectation regarding the interactive effects of interest groups' interests in European policies and parties' positions towards the EU on the likelihood of contact between groups and parties. In Model 1, we analyse the effects that each of these two variables have without explicitly including an interaction term between them. In logistic regression models, interactions be- tween two variables may be present even in the absence of an interaction term in the model (Berry, DeMeritt, \& Esarey, 2010). The model demonstrates that both interest groups' European policy interests and party EU positions matter for the likelihood of contact between groups and parties. Importantly, both of these effects are quite substantial: Keeping all other covariates constant at their mean or their reference value (for categorical variables), the model predicts groups for whom policies originating at the EU level are (the most) important to be 25 per-

Table 2. Mixed effects logistic regression explaining contact between interest groups and political parties.

\begin{tabular}{|c|c|c|}
\hline & \multicolumn{2}{|c|}{ DV: Contact } \\
\hline & $(1)$ & $(2)$ \\
\hline \multicolumn{3}{|l|}{ IGinterest in EU public policy } \\
\hline no importance whatsoever & Ref. & Ref. \\
\hline less important & $.34(.27)$ & $-.37(.44)$ \\
\hline important/most important & $1.15 * * *(.29)$ & $.36(.46)$ \\
\hline Party EU position & $.18 *(.11)$ & $.04(.12)$ \\
\hline \multicolumn{3}{|l|}{ Interaction effects } \\
\hline European policy less important for IG * Party EU position & & $.18 * * *(.06)$ \\
\hline European policy (most) important for IG *Party EU position & & $.19 * * *(.07)$ \\
\hline \multicolumn{3}{|l|}{ Control variables } \\
\hline EU salience & $.17 *(.09)$ & $.18 * *(.09)$ \\
\hline Left-Right position & $.32(.89)$ & $.32(.89)$ \\
\hline Left-Right position ${ }^{2}$ & $-.01(.09)$ & $-.02(.09)$ \\
\hline GAL-TAN position & $.45 * * *(.17)$ & $.44 * *(.17)$ \\
\hline GAL-TAN position ${ }^{2}$ & $-.06 * * *(.02)$ & $-.06 * * *(.02)$ \\
\hline Seat share & $.05 * * *(.01)$ & $.05 * * *(.01)$ \\
\hline Government & $.10(.27)$ & $.13(.27)$ \\
\hline Populist & $-.13(.35)$ & $-.14(.36)$ \\
\hline Institutionalisation (Party age logged) & $.79 * * *(.15)$ & $.82 * * *(.15)$ \\
\hline Breadth of policy engagement & $.20 * * *(.03)$ & $.20 * * *(.03)$ \\
\hline Resources & $.64 * * *(.08)$ & $.63 * * *(.08)$ \\
\hline \multicolumn{3}{|l|}{ Group type } \\
\hline Other group & Ref. & Ref. \\
\hline Business group & $.80 * * *(.29)$ & $.81 * * *(.30)$ \\
\hline Citizen group & $.94 * * *(.31)$ & $.95 * * *(.31)$ \\
\hline Institutional group & $1.80 * * *(.47)$ & $1.79 * * *(.48)$ \\
\hline Union & $2.11 * * *(.48)$ & $2.31 * * *(.48)$ \\
\hline \multicolumn{3}{|l|}{ Country fixed effects } \\
\hline Belgium & Ref. & Ref. \\
\hline Netherlands & $1.16 * * *(.40)$ & $1.17 * * *(.40)$ \\
\hline Lithuania & $-.92 *(.48)$ & $-.96 * *(.49)$ \\
\hline Slovenia & $-2.40 * * *(.57)$ & $-2.49 * * *(.57)$ \\
\hline Italy & $.32(.57)$ & $.36(.57)$ \\
\hline Intercept & $-10.33 * * *(2.15)$ & $-9.78 * * *(2.17)$ \\
\hline Group intercept variance & 12.93 & 13.16 \\
\hline Party intercept variance & .20 & .20 \\
\hline $\mathrm{N}_{\text {Dyads }}$ & 16,514 & 16,514 \\
\hline $\mathrm{N}_{\text {Groups }}$ & 2,067 & 2,067 \\
\hline $\mathrm{N}_{\text {Parties }}$ & 38 & 38 \\
\hline Log likelihood & $-6,606.05$ & $-6,601.29$ \\
\hline
\end{tabular}

Notes: Entries are logit coefficients; ${ }^{*} \mathrm{p}<0.1 ;{ }^{* *} \mathrm{p}<0.05 ;{ }^{* * *} \mathrm{p}<0.01$; standard errors in parentheses. 
centage points more likely to contact a given party than groups for whom EU policy is not important. Likewise, parties who are strongly opposed to European integration are 15 percentage points less likely to have contact with a given interest group than parties who are strongly in favour of European integration.

These findings hold for our second model in which we include the interaction effect between groups' European policy interests and party positions towards European integration. When looking at Model 2, we notice that the main coefficients of groups' European policy interests are no longer significant and that both main effects included in the interaction substantially decreased in size. However, both interaction coefficients are different from zero $(p<.01)$ which indicates that the two factors are indeed jointly affecting the likelihood of contact.

How do they do so? In order to gain a better understanding of the estimated effects of group interests in, and party positions towards, the EU, we computed the average marginal predicted probabilities of contact for all possible combinations of parties' EU positions, and groups' European policy interests. We plot these in Figure 1. To ease interpretability, we do not display combinations with groups for whom European policy is less important (our middle category).

As can be seen, the figure provides broad support for our two hypotheses. To begin, in line with $\mathrm{H} 1$, the steeply rising dotted line illustrates that interest groups whose policy interests are dealt with at the EU level are substantially more likely to have contact with pro-European parties than with parties that oppose European integration.
Next, the figure reveals that groups for whom EU policy is an important or the most important focus become significantly more likely to contact a given party when this party is at least in favour of European integration, as compared to interest groups for whom EU policy is not important. When parties are neutral, or opposed to European integration, the largely overlapping confidence intervals indicate that there is no significant difference between interest groups.

Last, even though the predicted probabilities of contact between interest groups without substantive European policy interests rise marginally the more proEuropean parties become, this increase is much smaller than for EU-interested interest groups and is not statistically significant. This means that, in line with $\mathrm{H} 2$, despite the fact that they are slightly more drawn to pro-European parties, groups without substantive European policy interests are not distinctly affected by party positions concerning European integration. Overall, the analyses lend broad support to our theoretical argument that interest groups whose long-term policyspecific priorities are related to issues addressed in the EU multi-level setting, avoid parties whose opposition to European integration crosscut their prime policy objectives.

Finally, considering the control variables, we note that while not all the explanations are significantly different from zero, they all point in the expected direction. We find that contact between interest groups and parties is more likely if European integration is a more salient issue for a party, if parties take left or moder-

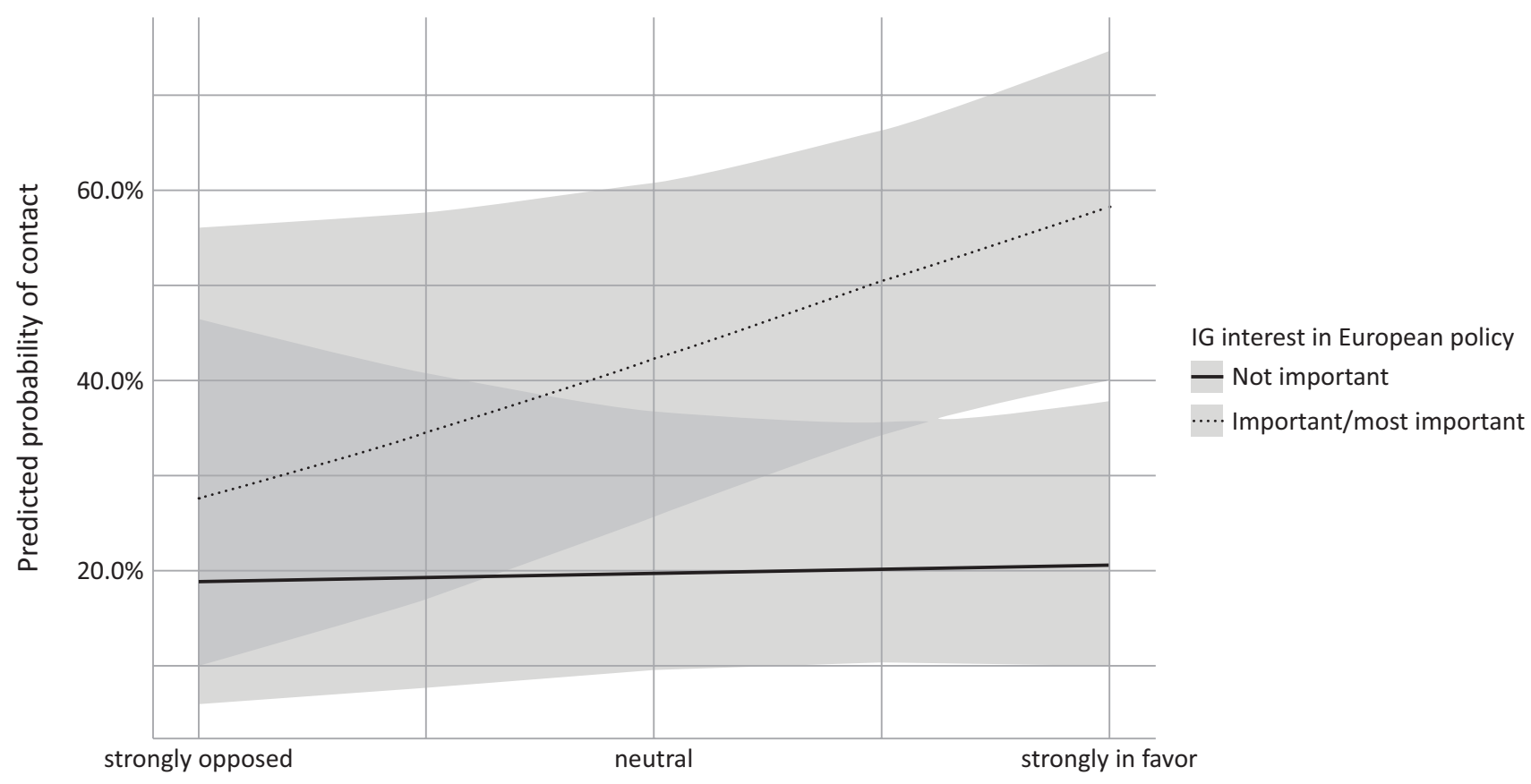

Party position towards European integration

Figure 1. Interaction between groups' interest in EU public policy and parties' position towards the EU. Notes: The figure shows average marginal predicted probabilities with $95 \%$ confidence intervals, based on Model 2 . Groups for whom European policy is less important are omitted from the graph to ease interpretation (full graph available from the authors). 
ate positions on the GAL-TAN dimension, if they are larger in parliament, and if they are older. In contrast, ideological positions on the left-right dimension, government participation, or being populist does not affect the likelihood of contact. Perhaps these null findings are due to some collinearity between these measures and similar ones included in the model. However, it is also conceivable that parties with more extreme economic positions, for example, are simply less of a threat to groups' maintenance goals than anticipated. With regard to group-level variables, we find support for the assertion that groups capable of delivering relevant policy information and interested in a wide range of topics, i.e., groups with more resources and a broader policy engagement, are more likely to have contact with parties than groups with fewer resources or narrower policy interests. Less substantially important, but noteworthy nonetheless, there are differences between interest group types. We also note an interesting division between Eastern and Western European countries. Contact between interest groups and parties is generally less likely in Lithuania and Slovenia than in Belgium, the Netherlands, or Italy.

\section{Conclusion}

Our article contributes to a recent wave of studies on the substantive change in the meaning of the dominant cleavage in politics. These studies highlight that socialcultural positions related to the EU often supersede the 'classic' socio-economic positions of parties. The issue we sought to address is how much this shift has affected interest group-party relations in five EU countries and, more precisely, the extent to which parties' stances towards the EU determine whether interest groups have contact with them.

Our principal conclusion has two aspects. First, we find that 'the big game is the party game.' With this, we do not imply that legislators provide interest groups with their most important channel into politics (they, at least, share that position with executive actors). We mean that party-political conflict contaminates or even dominates the narrow issue conflicts in which interest groups are commonly involved. That is, if interest groups are affected by EU policies, a party's position towards the $\mathrm{EU}$ is one the most critical cues governing the willingness of interest groups to stay in contact, favouring proEU parties. Importantly, we find this after controlling for other factors, including the party's alignment on other critical issues such as socio-economic positions and other cultural-social stances. Our second contribution is more specific to the interest groups literature. We find that interest group-party relations are heavily structured by the policy instruments chosen. This is traditionally conceived of in terms of the so-called Lowi-Wilson matrix of the cost-benefit distributions of policies (Wilson, 1980). However, in this case, it refers to the shape of the 'policy terrain' (e.g., Hacker \& Pierson, 2014, pp. 645-648) in terms of the particular distribution of policy compe- tences between the EU and its members states. This particular multi-level distribution of competences within policy areas sets the contours of the political incentives to coalesce, oppose, support, and coordinate with other actors (for a similar assessment see HeinkelmannWild, Kriegmair, \& Rittberger, 2020); particularly given the party-political politicisation of European integration as an issue. Our study suggests that we need a more precise understanding of how these policy area-specific dynamics are connected to broader political oppositions in the party system and beyond.

Our findings have several consequences. First, political parties that voice Eurosceptic political positions may represent particular sub-sections of the electorate but they burn bridges with many interest groups whose interests are affected by EU public policy. This makes it more difficult to take responsibility for substantive changes in public policy by means of networks of contacts with interest representatives. This potentially splits party systems throughout Europe between parties who meaningfully voice legitimate Eurosceptic positions, but who can or do not take government responsibility, and political parties who avoid the EU issue, or take pro-EU positions and retain viability as responsible officeholders (this adds to the incentives in the same direction noted by Lefkofridi, 2020). This contributes to what Mair (2009) identified as the 'bifurcation of party systems.' Future studies could assess whether such bifurcation actually occurs and how it varies across countries.

Second, due to the multidimensionality of party conflict and the multi-level nature of decision-making in Europe, it becomes increasingly difficult for interest groups and parties to find natural allies and establish long-term contacts among each other. One could argue that this is beneficial as it leads to more open, perhaps more democratically legitimate, decision-making. Nevertheless, there are also disadvantages, as it potentially also leads to more opportunistic coalitions of parties and interest groups focussed on short-term gains, rather than long-term stability (Mizruchi, 2013, p. 4; Olson, 1982). It could also result in the representation of only those interests which manage to vertically and horizontally venue-shop along favourably deposed political environments. Future studies may assess such implications for political outcomes.

This bring us to our third consideration: It is not yet clear who are the winners and losers in the interest group community due to the changes outlined above. Does this enable more opportunities for wealthy, business-like organisations, or do other types of interests gain more? For instance, one could argue that business groups lose if EU scepticism trumps economic reasoning in policymaking. Brexit, which has been fiercely opposed by the majority of the businesses in the United Kingdom, is perhaps the most apparent example. Yet, on other issues, it may also increase opportunities for the business community as the debates about the distributional consequences of policies are deprioritised in favour of political debate 
concerning socio-cultural issues. For instance, important competing firms can easily free ride on NGO opposition to trade agreements such as the Transatlantic Trade and Investment Partnership. Future studies should therefore seek to explain how party relations affect policy output, thereby assessing the primary winners and losers of political conflict.

\section{Acknowledgments}

We are grateful to Jan Beyers for initiating and organizing the 'Comparative Interest Group Survey' and the different country teams for the surveys in the respective countries. We thank the European Research Council (ERC-2013-CoG 616702-iBias, principal investigator Jan Beyers) for its financial contribution. We also benefited from the financial support of the NWO (Hanegraaff VENI grant: 451-16-016 \& Berkhout ORA grant: 464-15-148).

\section{Conflict of Interests}

The authors declare no conflict of interests.

\section{Supplementary Material}

Supplementary material for this article is available online in the format provided by the authors (unedited).

\section{References}

Allern, E. H., \& Bale, T. (2012). Political parties and interest groups: Disentangling complex relationships. Party Politics, 18(1), 7-25.

Allern, E. H., Hansen, V. W., Otjes, S., Rasmussen, A., Røed, M., \& Bale, T. (2019). All about the money? A cross-national study of parties' relations with trade unions in 12 western democracies. Party Politics. Advance online publication. https://doi.org/10.1177/ 1354068819862143

Baumgartner, F. R., \& Leech, B. L. (2001). Interest niches and policy bandwagons: Patterns of interest group involvement in national politics. The Journal of Politics, 63(4), 1191-1213.

Bawn, K., Cohen, M., Karol, D., Masket, S., Noel, H., \& Zaller, J. (2012). A theory of political parties: Groups, policy demands and nominations in American politics. Perspectives on Politics, 10(3), 571-597.

Berkhout, J., Hanegraaff, M., \& Statsch, P. (2019). Explaining the patterns of contacts between interest groups and political parties: Revising the standard model for populist times. Party Politics. Advance online publication. https://doi.org/10.1177\% 2F1354068819856608

Berry, W. D., DeMeritt, J. H. R., \& Esarey, J. (2010). Testing for interaction in binary logit and probit models: Is a product term essential? American Journal of Political Science, 54(1), 248-266.

Beyers, J., de Bruycker, I., \& Baller, I. (2015). The align- ment of parties and interest groups in EU legislative politics: A tale of two different worlds? Journal of European Public Policy, 22(4), 534-551.

Beyers, J., Bernhagen, P., Boräng, F., Braun, C., FinkHafner, D., Heylen, F., . . . Pakull, D. (2016). Comparative Interest Group Survey questionnaire (Edition: January 2016). Comparative Interest Group Survey. Retrieved from https://www.cigsurvey.eu/data

Beyers, J., Dür, A., \& Wonka, A. (2018). The political salience of EU policies. Journal of European Public Policy, 25(11), 1726-1737.

Bolleyer, N. (2017). Political actors: Parties-interest groups-government. In H. Keman \& J. Woldendorp (Eds.), Handbook of research methods and applications in political science (pp. 141-154). Cheltenham: Edward Elgar.

Braun, D., Popa, S. A., \& Schmitt, H. (2019). Responding to the crisis: Eurosceptic parties of the left and right and their changing position towards the European Union. European Journal of Political Research, 58(3), 797-819.

Burstein, P. (1998). Interest organizations, political parties, and the study of democratic politics. In A. N. Costain \& A. S. McFarland (Eds.), Social movements and American political institutions (pp. 39-56). Lanham, MD: Rowman and Littlefield.

Burstein, P., Einwohner, R. L., \& Hollander, J. A. (1995). The success of political movements: A bargaining perspective. In J. C. Jenkins \& B. Klandermans (Eds.), The politics of social protest: Comparative perspectives on states and social movements (pp. 275-294). Minneapolis, MN: University of Minnesota Press.

Císař, O., \& Vráblíková, K. (2019). National protest agenda and the dimensionality of party politics: Evidence from four East-Central European democracies. European Journal of Political Research, 58(4), 1152-1171.

de Bruycker, I. (2016). Power and position: Which EU party groups do lobbyists prioritize and why? Party Politics, 22(4), 552-562.

de Bruycker, I. (2017). Politicization and the public interest: When do the elites in Brussels address public interests in EU policy debates? European Union Politics, 18(4), 603-619.

de Bruycker, I. (2019). Democratically deficient, yet responsive? How politicization facilitates responsiveness in the European Union. Journal of European Public Policy. Advance online publication. https://doi. org/10.1080/13501763.2019.1622587

de Vries, C. E. (2018a). Euroscepticism and the future of European integration. Oxford and New York, NY: Oxford University Press.

de Vries, C. E. (2018b). The cosmopolitan-parochial divide: Changing patterns of party and electoral competition in the Netherlands and beyond. Journal of European Public Policy, 25(11), 1541-1565.

de Vries, C. E., Hakhverdian, A., \& Lancee, B. (2013). The dynamics of voters' left/right identification: The role of economic and cultural attitudes. Political Science 
Research and Methods, 1(2), 223-238.

de Wilde, P., Leupold, A., \& Schmidtke, H. (2016). Introduction: The differentiated politicization of European governance. West European Politics, 39(1), 3-22.

Döring, H., \& Manow, P. (2018). Parliaments and governments database (ParlGov): Information on parties, elections and cabinets in modern democracies. Retrieved from https://doi.org/10.7910/DVN/FOYGNC

Farrer, B. (2014). A theory of organizational choice: Interest groups and parties as substitutable influence mechanisms. Party Politics, 20(4), 632-645.

Fraussen, B., \& Halpin, D. R. (2018). Political parties and interest organizations at the crossroads: Perspectives on the transformation of political organizations. Political Studies Review, 16(1), 25-37.

Grossmann, M. (2014). Artists of the possible: Governing networks and American policy since 1945. Oxford and New York, NY: Oxford University Press.

Hacker, J. S., \& Pierson, P. (2014). After the "master theory": Downs, Schattschneider, and the rebirth of policy-focused analysis. Perspectives on Politics, 12(3), 643-662.

Hall, R. L., \& Deardorff, A. V. (2006). Lobbying as legislative subsidy. American Political Science Review, 100(1), 69-84.

Halpin, D. (2011). Explaining policy bandwagons: Organized interest mobilization and cascades of attention. Governance, 24(2), 205-230.

Hanegraaff, M. C., \& Berkhout, J. (2018). More business as usual? Explaining business bias across issues and institutions in the European Union. Journal of European Public Policy, 26(6), 843-862.

Hanegraaff, M. C., \& Pritoni, A. (2019). United in fear: Interest group coalition formation as a weapon of the weak? European Union Politics, 20(2), 198-218.

Heinkelmann-Wild, T., Kriegmair, L., \& Rittberger, B. (2020). The EU multi-level system and the Europeanization of domestic blame games. Politics and Governance, 8(1), 85-94.

Hobolt, S. B. (2016). The Brexit vote: A divided nation, a divided continent. Journal of European Public Policy, 23(9), 1259-1277.

Hobolt, S. B., \& de Vries, C. E. (2015). Issue entrepreneurship and multiparty competition. Comparative Political Studies, 48(9), 1159-1185.

Hoeglinger, D. (2016). The politicisation of European integration in domestic election campaigns. West European Politics, 39(1), 44-63.

Hooghe, L., \& Marks, G. (2018). Cleavage theory meets Europe's crises: Lipset, Rokkan, and the transnational cleavage. Journal of European Public Policy, 25(1), 109-135.

Hutter, S., \& Kriesi, H. (2019). Politicizing Europe in times of crisis. Journal of European Public Policy, 26(7), 996-1017.

Jordan, G., Halpin, D., \& Maloney, W. (2004). Defining interests: Disambiguation and the need for new distinctions? The British Journal of Politics and International
Relations, 6(2), 195-212.

Judge, A., \& Thomson, R. (2019). The responsiveness of legislative actors to stakeholders' demands in the European Union. Journal of European Public Policy, 26(5), 676-695.

Klüver, H. (2018). Setting the party agenda: Interest groups, voters and issue attention. British Journal of Political Science. Advance online publication. https:// doi.org/10.1017/S0007123418000078

Klüver, H., Braun, C., \& Beyers, J. (2015). Legislative lobbying in context: Towards a conceptual framework of interest group lobbying in the European Union. Journal of European Public Policy, 22(4), 447-461.

Lefkofridi, Z. (2020). Competition in the European arena: How the rules of the game help nationalists gain. Politics and Governance, 8(1), 41-49.

Lipset, S. M., \& Rokkan, S. (1967). Cleavage structures, party systems, and voter alignments. In S. M. Lipset \& S. Rokkan (Eds.), Party systems and voter alignments: Cross-national perspectives (pp. 1-64). New York, NY: Free Press.

Lowery, D., \& Gray, V. (2004). Bias in the heavenly chorus: Interests in society and before government. Journal of Theoretical Politics, 16(1), 5-30.

Mair, P. (1997). Party system change: Approaches and interpretations. Oxford: Oxford University Press.

Mair, P. (2009). Representative versus responsible government (Working Paper 09/8). Cologne: Max Planck Institute for the Study of Societies. Retrieved from http://www.mpifg.de/pu/workpap/wp09-8.pdf

Marks, G., Hooghe, L., Nelson, M., \& Edwards, E. (2006). Party competition and European integration in the East and West: Different structure, same causality. Comparative Political Studies, 39(2), 155-175.

Meijers, M., \& Rauh, C. (2016). Has Eurosceptic mobilization become more contagious? Comparing the 2009 and 2014 EP election campaigns in the Netherlands and France. Politics and Governance, 4(1), 83-103.

Mizruchi, M. S. (2013). The fracturing of the American corporate elite. Cambridge, MA: Harvard University Press.

Olson, M. (1982). The rise and decline of nations. New Haven, CT: Yale University Press.

Otjes, S., \& Rasmussen, A. (2017). The collaboration between interest groups and political parties in multiparty democracies: Party system dynamics and the effect of power and ideology. Party Politics, 23(2), 96-109.

Pappi, F. U., \& Henning, C. H. (1999). The organization of influence on the EC's common agricultural policy: A network approach. European Journal of Political Research, 36(2), 257-281.

Pirro, A. L., Taggart, P., \& van Kessel, S. (2018). The populist politics of Euroscepticism in times of crisis: Comparative conclusions. Politics, 38(3), 378-390.

Polk, J., Rovny, J., Bakker, R., Edwards, E., Hooghe, L., Jolly, S., .. . Zilovic, M. (2017). Explaining the salience of anti-elitism and reducing political corruption for 
political parties in Europe with the 2014 Chapel Hill Expert Survey data. Research and Politics, 4(1), 1-9.

Rasmussen, A. (2012). Interest group-party interaction in EU politics. Party Politics, 18(1), 81-98.

Rasmussen, A., Carroll, B. J., \& Lowery, D. (2014). Representatives of the public? Public opinion and interest group activity. European Journal of Political Research, 53(2), 250-268.

Rasmussen, A., \& Lindeboom, G.-J. (2013). Interest group-party linkage in the twenty-first century: Evidence from Denmark, the Netherlands and the United Kingdom. European Journal of Political Research, 52(2), 264-289.

Rauh, C. (2019). EU politicization and policy initiatives of the European Commission: The case of consumer policy. Journal of European Public Policy, 26(3), 344-365.

Riker, W. H. (1996). The strategy of rhetoric: Campaigning for the American Constitution. New Haven, CT: Yale University Press.

Salisbury, R. H. (1969). An exchange theory of interest groups. Midwest Journal of Political Science, 13(1), 1-32.

Schattschneider, E. E. (1960). The semisovereign people: A realist view of democracy in America. New York, NY, Chicago, IL, San Francisco, CA, Toronto and London: Holt, Rinehart and Winston.

Schneider, C. J. (2018). The responsive union: National elections and European governance. Cambridge:
Cambridge University Press.

Szczerbiak, A., \& Taggart, P. (Eds.). (2008). Opposing Europe? The comparative party politics of Euroscepticism. Volume 2: Comparative and theoretical perspectives. Oxford and New York, NY: Oxford University Press.

Taggart, P. (1998). A touchstone of dissent: Euroscepticism in contemporary Western European party systems. European Journal of Political Research, 33(3), 363-388.

Truman, D. B. (1951). The governmental process: Political interests and public opinion. New York, NY: Alfred Knopf.

van der Brug, W., \& van Spanje, J. (2009). Immigration, Europe and the new cultural dimension. European Journal of Political Research, 48(3), 309-334.

van Elsas, E., \& van der Brug, W. (2015). The changing relationship between left-right ideology and Euroscepticism, 1973-2010. European Union Politics, 16(2), 194-215.

Volkens, A., Lehmann, P., Matthieß, T., Merz, N., Regel, S., \& Wessels, B. (2017). Manifesto project dataset (Version 2017b). Berlin: Wissenschaftszentrum Berlin Für Sozialforschung.

Wilson, J. Q. (1980). The politics of regulation. New York, NY: Basic Books.

Wonka, A. (2017). German MPs and interest groups in EU Multilevel policy-making: The politics of information exchange. West European Politics, 40(5), 1004-1024.

\section{About the Authors}

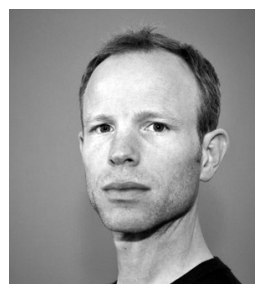

Joost Berkhout is Associate Professor in the Department of Political Science at the University of Amsterdam. He is specialized in research on interest organizations.

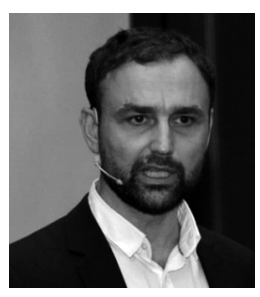

Marcel Hanegraaff is an Associate Professor in Political Science at the University of Amsterdam. He researches the politics of interest representation in a transnational and EU context, as well as on the functioning of international organizations in the fields of climate change and global trade.

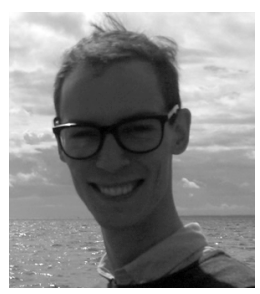

Patrick Statsch is PhD Candidate in Political Science at the University of Amsterdam. For his PhD project he is investigating various ways of interaction between interest groups and political parties in established democracies. His research interests also include the European Union and electoral systems. Prior to working in Amsterdam, he studied in Bremen (BA) and Leiden (MSc). 